\title{
PENINGKATAN KOMPETENSI ANGGOTA KARANG TARUNA RW 14, DESA CIWARUGA DALAM INSTALASI LISTRIK RUMAH TANGGA
}

\author{
Tjatur Udjianto ${ }^{1}$, Agoeng Harjatmo Rahardjo ${ }^{1}$, Sudrajat $^{1}$, Siti Saodah $^{1}$, \\ Wahyu Budi Mursanto ${ }^{1}$, Erwin Yusuf ${ }^{1}$, Teguh Sasono ${ }^{1}$, Sri Utami ${ }^{1}$ \\ ${ }^{1}$ Jurusan Teknik Konversi Energi, Politeknik Negeri Bandung \\ Email: tjatur.udjianto@polban.ac.id
}

\begin{abstract}
Abstrak
Anggota karang taruna RW 14 di desa Ciwaruga sebagian besar merupakan pekerja bangunan. Kadang, mereka dituntut untuk melakukan pekerjaan instalasi listrik. Karena tidak semua pekerja bangunan mengerti pekerjaan dan syarat-syarat instalasi listrik, maka mereka bekerja seadanya tanpa memperhatikan syarat-syarat dan keamanan instalasi listrik yang sebenarnya telah diatur pada PUIL 2011 (Persyaratan Umum Instalasi Listrik 2011). Dari permasalahan tersebut, solusi yang ditawarkan adalah melakukan kegiatan bimbingan teknis untuk meningkatkan kompetensi anggota karang taruna RW14 desa Ciwaruga dalam Instalasi Listrik Bangunan Sederhana dan mengenalkan sertifikasi keahlian yang harus dimiliki oleh instalatur listrik apabila melakukan pekerjaan instalasi listrik. Metode pelaksanaan bimbingan teknis ini berupa pemberian test, materi dan evaluasi. Materi yang diberikan dalam kegiatan tersebut adalah; K3, Kelistrikan dan Pengukuran, Gambar Listrik dan Praktik Instalasi Listrik yang mengacu pada PUIL 2011. Kegiatan ini dapat dikatakan berhasil, ini terlihat dari hasil tes yang diberikan sebelum dan sesudah kegiatan bimbingan teknis diberikan. Saat diberikan pre-test, peserta tampak belum begitu memahami materi yang akan diberikan. Sedangkan setelah diberikan materi, dari hasil post-test yang diberikan terlihat banyak peserta yang memahami materi yang telah diberikan.
\end{abstract}

Kata kunci: Instalasi listrik, peningkatan kompetensi, PUIL 2011

\section{PENDAHULUAN}

Desa Ciwaruga merupakan desa tempat Politeknik Negeri Bandung berada. Masyarakat desa Ciwaruga memiliki mata pencaharian utama sebagai petani, pedagang, dan buruh bangunan. Walaupun, masih banyak pula yang belum mendapatkan pekerjaan. Masyarakat desa Ciwaruga memiliki rata-rata tingkat pendidikan sederajat SLTA. Terdapat beberapa perkumpulan warga di desa Ciwaruga, seperti PKK, karang taruna, remaja masjid, dan lain-lain. Dengan adanya perkumpulan ini, warga, terutama pemuda desa Ciwaruga dapat menemukan tempat untuk berkegiatan. Perkumpulan-perkumpulan tersebut rata-rata memiliki anggota 30-60 orang, dengan 
DIFUSI

Volume 3, No.2 Juli 2020

mayoritas pemuda yang tidak memiliki pekerjaan tetap.

Karang taruna RW14 merupakan salah satu perkumpulan di Desa Ciwaruga. Karang taruna RW14 memiliki anggota aktif sekitar 40 orang, terdiri dari anakanak muda yang memiliki berbagai macam profesi berbeda. Karang Taruna ini mulai aktif kembali pada tahun 2017 setelah tidak berkegiatan beberapa tahun sebelumnya sejak awal berdirinya pada tahun 1980an. Salah satu kegiatan karang taruna yang mulai dilakukan kembali pada tahun 2017 adalah kegiatan yang diberi nama Panci Mas, yaitu penyediaan air minum sehat gratis. Selain itu, terdapat pula kegiatan anggota karang taruna yang beririsan dengan kegiatan perkumpulan lainnya seperti kegiatan yang biasa dilakukan di masjid Babussalam (masjid di RW 14) seperti peringatan hari-hari besar keagamaan serta kegiatan di madrasah seperti pengajian untuk masyarakat lingkungan sekitar.

Banyak anggota karang taruna RW 14 berprofesi sebagai pekerja bangunan. Mereka terkadang dituntut oleh pemberi kerja untuk melakukan pekerjaan instalasi listrik. Akan tetapi kadang pekerjaan yang harus mereka lakukan tersebut tidak didukung oleh pengetahuan yang cukup. Sehingga hasil pekerjaan instalasi yang dilakukan tidak sesuai dengan pengetahuan dan persyaratan yang ada. Gambar 1 adalah contoh instalasi listrik hasil pekerjaan dari pekerja bangunan anggota karang taruna RW14, berdasarkan hasil kunjungan lapangan yang dilakukan pada bulan Maret 2019, dari gambar tersebut terlihat bahwa pekerjaan instalasi listrik yang dilakukan oleh pekerja bangunan tersebut tidak memperhatikan persyaratan keamanan dan keselamatan instalasi, dimana persyaratan untuk pekerjaan instalasi telah diatur oleh PUIL 2011.

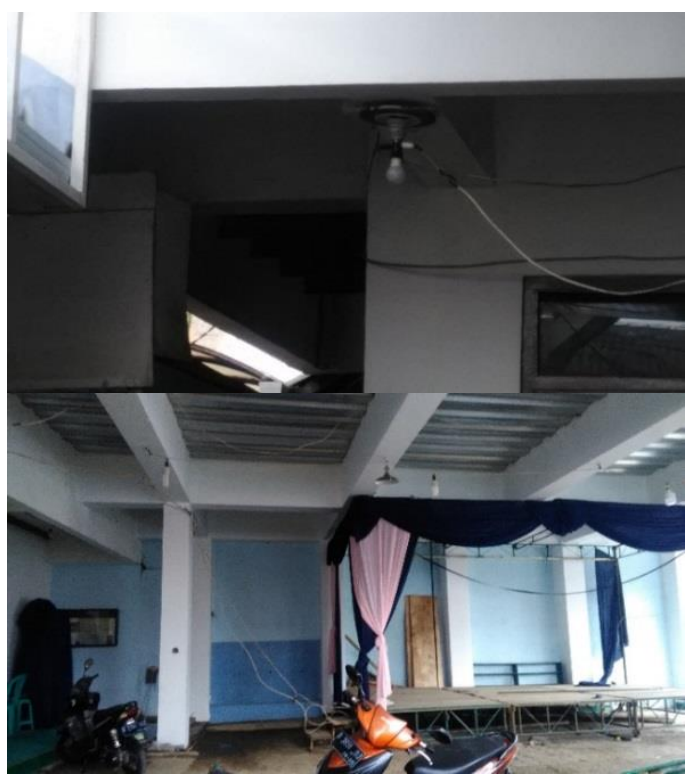

Gambar 1. Contoh Hasil Pekerjaan Instalasi Pekerjaan Bangunan Anggota Karang Taruna RW14

\section{METODE}

Berdasarkan latar belakang yang telah dipaparkan sebelumnya, diperlukan usaha atau kegiatan untuk meningkatkan kompetensi anggota karang taruna di dalam pekerjaan instalasi listrik. Untuk itu, tim PkM JTKE (Jurusan Teknik Konversi Energi) berupaya mengajukan program kemitraan masyarakat untuk dapat melakukan bimbingan teknis untuk dapat meningkatkan kompetensi anggota karang taruna RW14 desa Ciwaruga di bidang instalasi listrik. Adapun metode pelaksanaan kegiatan sebagaimana ditampilkan pada Gambar 2. 


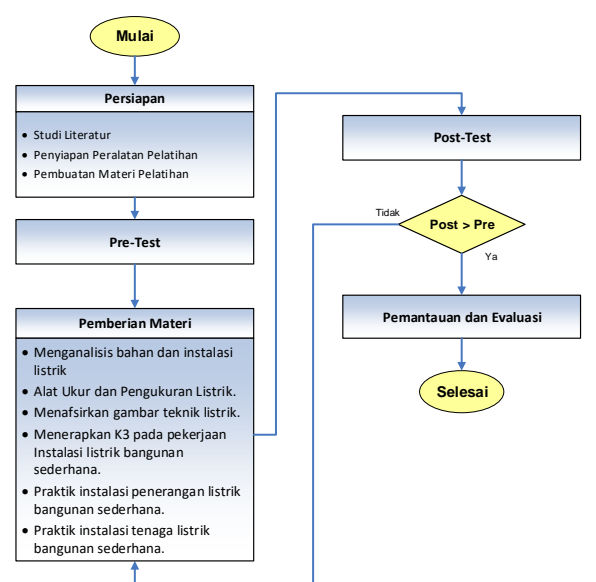

Gambar 2. Metode Pelaksanaan Pengabdian Masyarakat di Desa Ciwaruga

Penjabaran metode pelaksanaan pada Gambar 2 tersebut adalah sebagai berikut:

\section{Tahap Persiapan}

Tahap persiapan terdiri dari studi literatur, persiapan alat dan bahan dan pembuatan modul bimbingan teknis.

\section{a. Studi Literatur}

Dari studi literatur didapatkan materi untuk meningkatkan kompetensi anggota karang taruna RW14 desa Ciwaruga dalam Instalasi Listrik Bangunan Sederhana dan tata cara untuk mengenalkan sertifikasi keahlian yang harus dimiliki oleh instalatur listrik apabila melakukan pekerjaan instalasi listrik. Untuk seorang instalatur listrik, Standar Kompetensi Kerja Nasional Indonesia (SKKNI) memberikan acuan sertifikat Keahlian Teknik Instalasi Tenaga Listrik. Untuk melakukan pekerjaan Instalasi Listrik Bangunan Sederhana maka diperlukan tingkat keahlian dengan kode SKKNI
KTL.IK02.118.01 dengan kompetensi mampu Memasang Instalasi Listrik Bangunan Sederhana (Rumah Tinggal, Sekolah, Rumah Ibadah). Pengetahuan dan keterampilan yang harus dimiliki seorang instalatur dengan kualifikasi tersebut adalah [1]:

i. Pemahaman tentang bahan listrik.

ii. Pemahaman tentang Instalasi Listrik.

iii. Pemahaman tentang elektronika digital.

iv. Pemahaman tentang elektronika analog.

v. Pemahaman tentang teori listrik dasar.

vi. Pemahaman tentang alat ukur dan pengukuran listrik.

vii. Pemahaman tentang $\mathrm{k} 3$ perakitan dan pemasangan instalasi listrik bangunan sederhana.

viii. Keterampilan konstruksi instalasi listrik bangunan sederhana (rumah tinggal, sekolah, rumah ibadah).

ix. Keterampilan untuk merakit dan memasang peralatan instalasi listrik bangunan sederhana (rumah tinggal, sekolah, rumah ibadah) sesuai gambar rancangan.

x. Memahami Persyaratan Umum Instalasi Listrik (PUIL).

Mengingat keterbatasan waktu, peralatan, dan biaya, materi yang diberikan pada peserta untuk memenuhi kualifikasi SKKNI KTL.IK02.118.01 dipadatkan menjadi 6 (enam) materi sebagai berikut: 
i. Menganalisis bahan dan instalasi listrik

ii. Alat Ukur dan Pengukuran Listrik.

iii. Menafsirkan gambar teknik listrik [2].

iv. Menerapkan K3 pada pekerjaan Instalasi listrik bangunan sederhana.

v. Praktik instalasi penerangan listrik bangunan sederhana.

vi. Praktik instalasi tenaga listrik bangunan sederhana.

\section{b. Persiapan Alat dan Bahan}

Dalam hal persiapan alat dan bahan, tim PkM dan mitra saling berkoordinasi untuk persiapan pelaksanaan kegiatan pengabdian untuk memfasilitasi sarana dan bahan serta peralatan yang dibutuhkan selama kegiatan PKM berlangsung. Sarana prasarana akan disediakan oleh mitra, sedangkan bahan dan peralatan akan disediakan oleh tim PkM.

\section{c. Pembuatan Modul Bimbingan Teknis}

Modul Bimbingan Teknis digunakan saat kegiatan bimbingan teknis. Modul bimbingan teknis tersebut berupa handout dan diberikan kepada peserta pada saat kegiatan berlangsung.

\section{Pelaksanaan Bimbingan Teknis}

Pelaksanaan Bimbingan Teknis oleh tim PKM JTKE memberikan bimbingan teknis instalasi listrik bangunan sederhana. Kegiatan bimbingan teknis ini dilaksanakan selama 5 kali pertemuan. Luaran dari kegiatan ini adalah Peningkatan pengetahuan dan skill peserta bimbingan teknis di bidang instalasi listrik.

\section{Pemantauan dan Evaluasi}

Tahap Pemantauan dan Evaluasi yaitu tahap pemantauan dari hasil kegiatan bimbingan teknis yang telah dilakukan, dimana indikator keberhasilan kerja dapat dilihat dari sejauh mana peningkatan kompetensi peserta bimbingan teknis dalam Instalasi Listrik Bangunan Sederhana, melalui pemberian pre test dan post test oleh tim PkM. Interview juga dilakukan kepada beberapa masyarakat peserta terkait dengan kepuasan dan dampak yang diterima setelah mengikuti kegiatan bimbingan teknis.

\section{HASIL DAN PEMBAHASAN}

1.

\section{Kegiatan PKM}

Kegiatan PkM "Peningkatan Kompetensi Anggota Karang Taruna RW14 Desa Ciwaruga dalam Instalasi Listrik Rumah Tangga", Kecamatan Parongpong, Kabupaten Bandung Barat telah berhasil dilakukan. Kegiatan ini berupa kegiatan bimbingan teknis dan pemberian materi mengenai; Bimbingan Teknik dengan materi mengenal listrik, bahaya listrik dan pengamanannya, Kelistrikan dan Pengukuran, Gambar Listrik, PUIL 2011 [3-5] dan Praktik instalasi dan proteksi listrik sederhana untuk bangunan sederhana.

Kegiatan ini diikuti oleh 20 orang peserta anggota karang taruna dari berbagai macam latar belakang pekerjaan dan pendidikan. Latar belakang pekerjaan peserta adalah pekerja bangunan, maha- 
siswa, hingga guru. Adapun latar belakang pendidikannya dari mulai lulusan SLTP sampai lulusan S1. Semua peserta sangat antusias mengikuti kegiatan PkM ini.

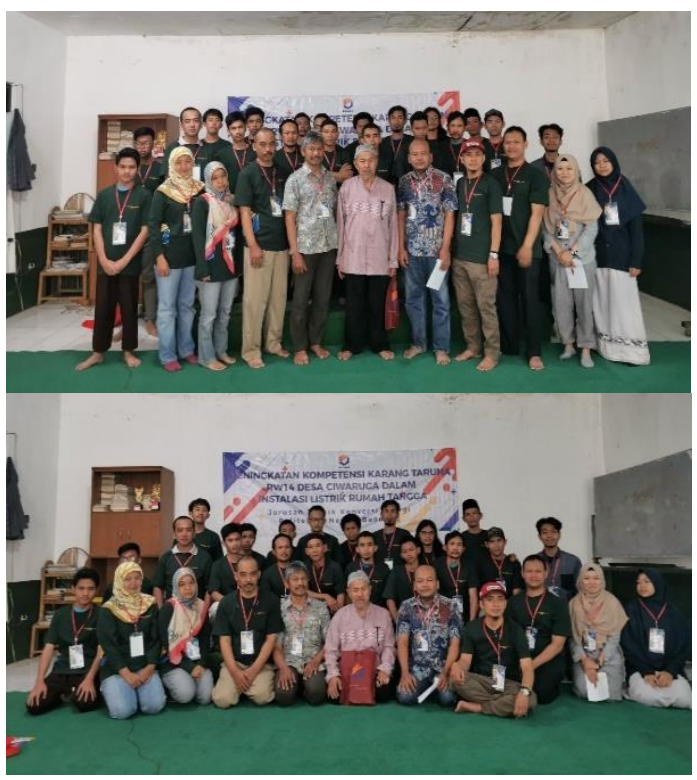

Gambar 3. Perserta Kegiatan PkM

"Peningkatan Kompetensi

KarangTaruna RW14 Desa Ciwaruga dalam Instalasi Listrik Bangunan Sederhana

Bimbingan teknis diawali dengan pemberian materi tentang mengenal listrik, bahaya listrik dan pengamanannya (Gambar 4). Ini dimaksudkan untuk meningkatkan kompetensi dalam menerapkan keselamatan dan kesehatan kerja (K3).

Materi kedua adalah ketenagalistrikan dan pengukuran (Gambar 5). Materi ini berisi peningkatan kompetensi tentang Menganalisis rangkaian listrik dan $\mathrm{Me}$ mahami dasar - dasar elektronika.

Materi ketiga dan keempat adalah gambar listrik dan pengenalan standar PUIL
2011 (Gambar 6). Kompetensi yang diharapkan dari materi tersebut adalah peserta mampu menafsirkan gambar teknik listrik sesuai standar PUIL 2011.

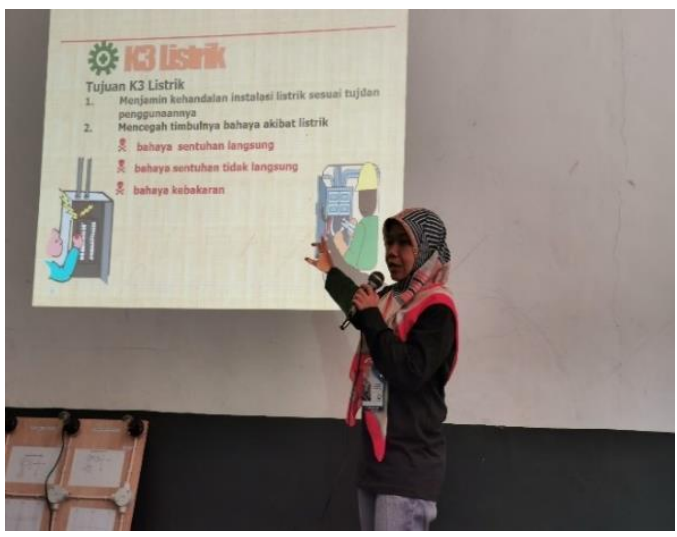

Gambar 4. Pemberian Materi Tentang Mengenal Listrik, Bahaya Listrik dan Pengamanannya

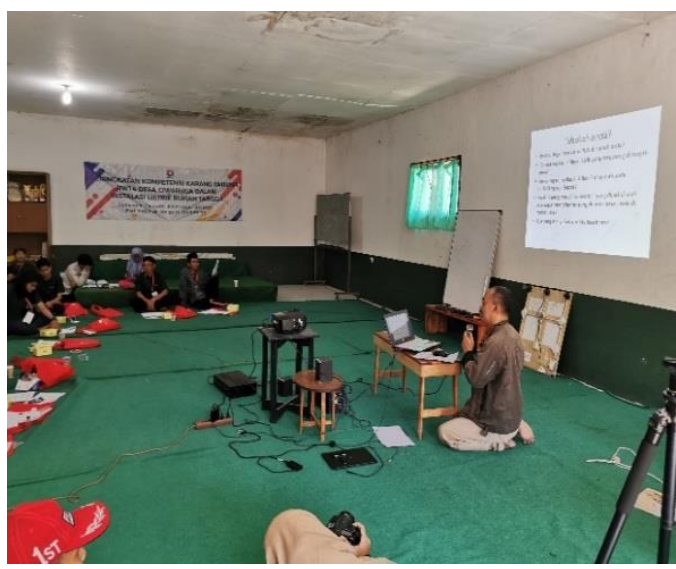

Gambar 5. Pemberian Materi Kelistrikan dan Pengukuran

Materi kelima adalah Praktek instalasi dan proteksi listrik sederhana untuk bangunan sederhana (Gambar 7). Kompetensi yang diharapkan dalam kegiatan ini adalah peserta mampu:

a. memasang instalasi penerangan listrik pada bangunan sederhana,

b. memasang instalasi tenaga listrik pada bangunan sederhana, 


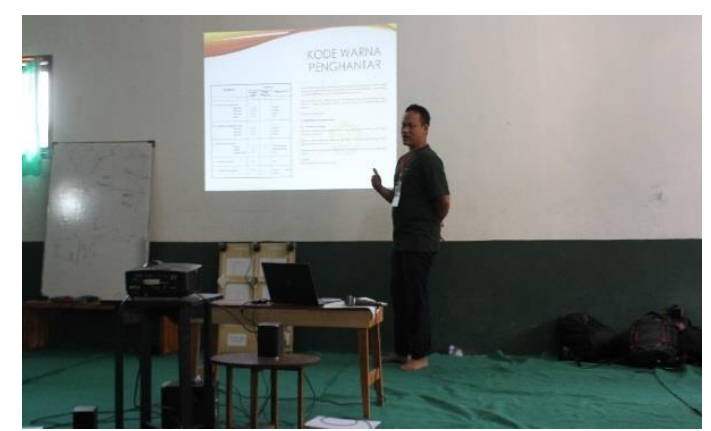

Gambar 6. Pemberian Materi Gambar Listrik dan Pengenalan Standar PUIL 2011

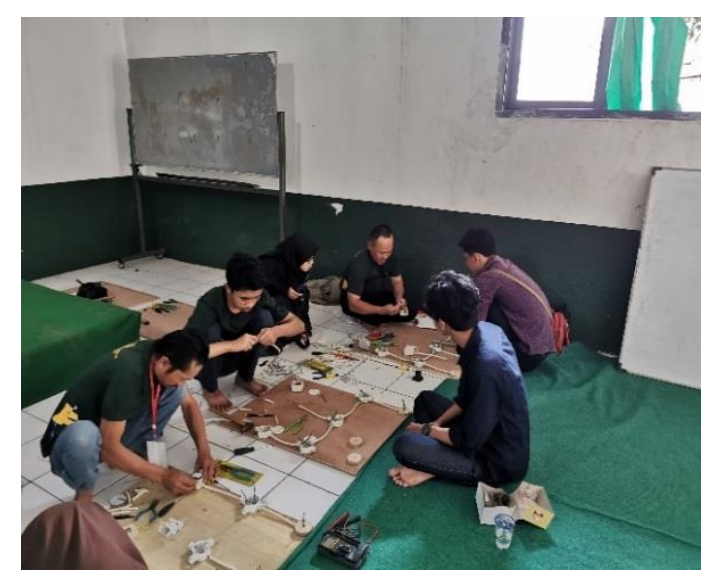

Gambar 7. Praktik Instalasi dan Proteksi Listrik Sederhana untuk Bangunan sederhana

\section{Pemantauan dan Evaluasi}

Pemantauan kegiatan PkM ini dilakukan dengan memberikan pertanyaan sebelum dan sesudah kegiatan berlangsung. Pertanyaan yang diberikan sebelum kegiatan dimaksudkan untuk mencari informasi tentang wawasan peserta $\mathrm{PkM}$ tentang materi instalasi listrik yang akan digunakan sebagai baseline. Pada pertemuan terakhir sebelum melakukan penutupan peserta diberikan kembali soal yang sama seperti sebelum melakukan bimbingan teknis. Ini dilakukan untuk mengukur penyerapan peserta terhadap materi yang diberikan oleh tim PkM. Hasil pemantauan ini digunakan sebagai bahan evaluasi peningkatan kompetensi peserta di dibidang instalasi listrik. Hasil pemantauan dipetakan pada Gambar 8 .

Dari pemetaan tersebut dapat dilihat bahwa, sebelum melakukan bimbingan teknis kami memberikan soal pre-test untuk mengetahui kemampuan dasar peserta, hasilnya adalah:

a. Peserta tidak mampu membedakan rangkaian mana yang dapat menghasilkan lampu nyala lebih terang (Q1);

b. Peserta tidak mengerti fungsi Grounding dalam instalasi listrik (Q2);

c. Peserta dapat mengenali gambargambar yang sering digunakan untuk peralatan listrik seperti Steker, stop kontak dan MCB (Miniature Circuit Breaker-pemutus jaringan bila terjadi arus lebih), khusus $\mathrm{MCB}$, walaupun peserta mampu mengenalinya peserta tidak dapat menghitung besarnya daya yang dapat ditampungnya (Q3, Q4, Q5).

d. Peserta tidak mengetahui simbolsimbol dari rangkaian listrik yang digunakan bertolak belakang jika peserta di berikan gambar yang sering peserta gunakan.(Q9, Q10, Q11, Q12) dapat dilihat baik dari gambar pemetaan (Gambar 8) pada Q9 sampai Q12 banyak sekali titik merah yang menandakan hasil pretest peserta tidak tahu atau tidak paham, dan dapat dilihat pada Error! Reference source not found. Q9 sampat Q12 nilainya berada dibawah rata-rata. 
DIFUSI

Volume 3, No.2 Juli 2020

e. Peserta tidak paham dengan warna kabel yang sesuai dengan SNI (Q13 dan Q14) dapat dilihat pada Gambar 9 nilainya dibawah rata-rata dan dilihat pada Gambar 8 banyak peserta yang mendapatkan titik merah atau warna merah.

f. Peserta sangat paham sekali tentang
Bahaya Listrik dibuktikan dengan banyaknya peserta yang hadir mengikuti acara bimbingan teknis ini dan mampu menjawab Q15 tentang bahaya listrik dan bagaimana mengamankan diri peserta agar tidak kesetrum $(\mathrm{Q} 8)$.

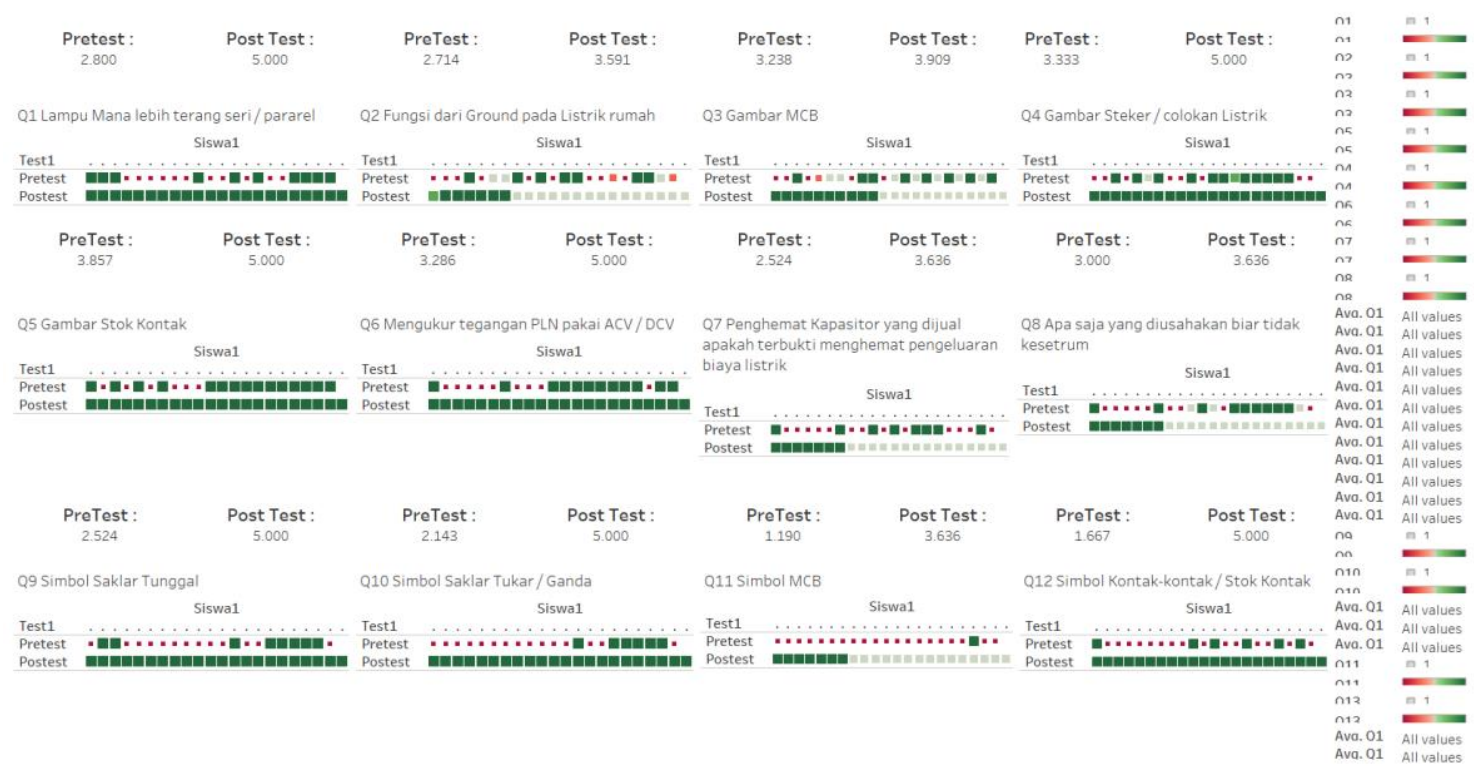

Gambar 8. Pemetaan Hasil Pretest \& Post test

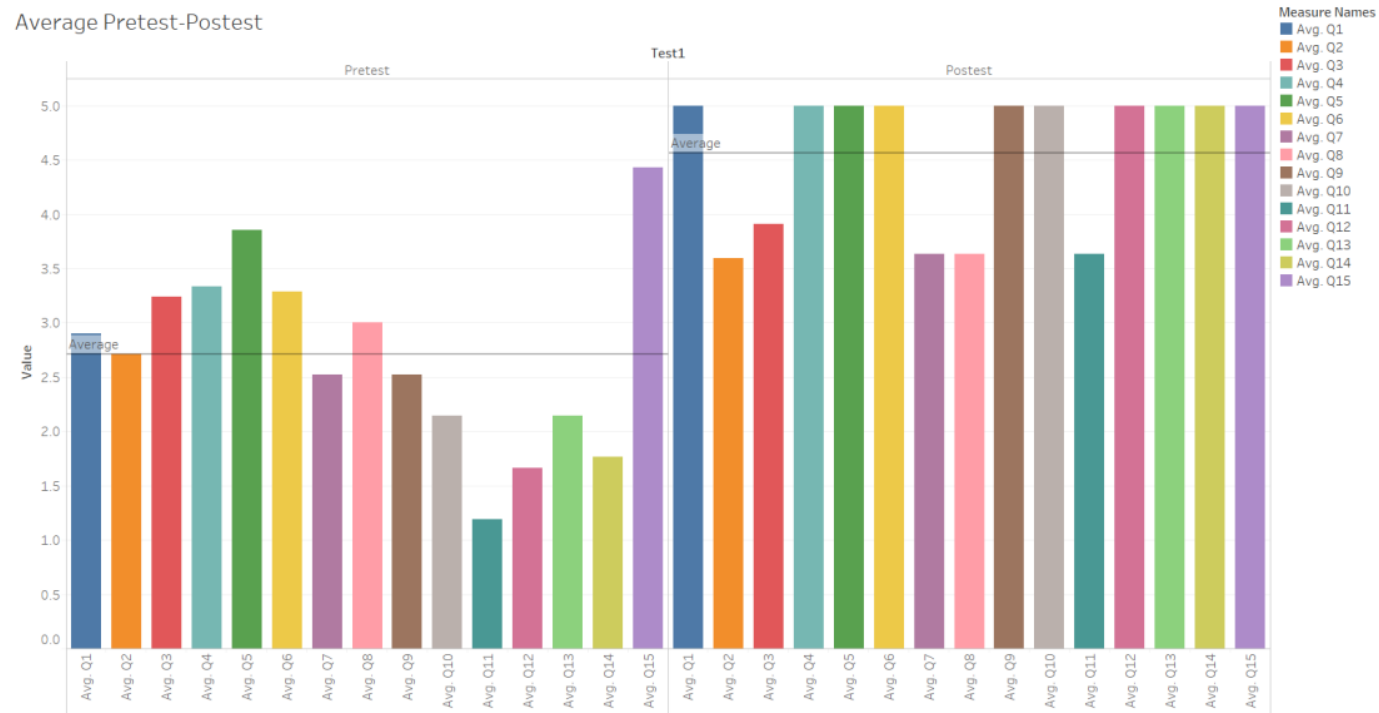

Gambar 9. Grafik Hasil Pretest dan PostTest 
DIFUSI

Volume 3, No.2 Juli 2020

Sedangkan hasil pemantauan saat posttest, hampir semua peserta dapat menjawab pertaanyan dengan benar. Ini ditunjukkan pada Berdasarkan evaluasi yang dilakukan, hasil dari bimbingan teknis ini sangat memuaskan berdasarkan poin-poin sebelumnya yang dianggap tidak tau ataupun kurang paham setelah melakukan bimbingan teknis ini peserta mampu dengan sangat baik menjawabnya. Sebagai contoh:

a. Peserta mampu mengerti pentingnya fungsi dari grounding atau pentanahan dibuktikan dilihat pada Error! Reference source not found. grafiknya diatas rata-rata.

b. Peserta mampu menghitung batas daya dari MCB.

c. Peserta mampu mengenali simbolsimbol listrik.

d. Peserta mampu melakukan instalasi listrik sesuai dengan SNI sehingga dapat meminimalisir resiko tersengat listrik ketika melakukan maintenance instalasi listrik.

\section{KESIMPULAN}

Kegiatan PkM "Peningkatan Kompetensi Anggota Karang Taruna RW14 Desa Ciwaruga dalam Instalasi Listrik Rumah Tangga", Kecamatan Parongpong, Kabupaten Bandung Barat telah berhasil dilakukan. Kegiatan ini diikuti oleh 20 orang peserta anggota karang taruna dari berbagai macam latar belakang pekerjaan dan pendidikan. Latar belakang pekerjaan peserta adalah pekerja bangunan, mahasiswa, hingga guru. Adapun latar belakang pendidikannya dari mulai lulusan SLTP sampai lulusan S1.
Berdasarkan evaluasi yang dilakukan, hasil dari bimbingan teknis ini sangat memuaskan dan kegiatan ini dapat dikatakan berhasil. Ini terlihat dari hasil tes yang diberikan sebelum dan sesudah kegiatan bimbingan teknis diberikan. Saat diberikan pre-test, peserta tampak belum begitu memahami materi yang akan diberikan. Sedangkan setelah diberikan materi, dari hasil post-test yang diberikan terlihat banyak peserta yang memahami materi yang telah diberikan. Ini berdasarkan poin-poin sebelumnya yang dianggap tidak tahu ataupun kurang paham setelah melakukan bimbingan teknis ini peserta mampu dengan sangat baik menjawabnya.

Sebagai saran, sebaiknya kegiatan bimbingan teknis ini dilanjutkan dengan:

1. Tema yang sama tetapi peserta yang berbeda, atau

2. Peserta yang sama dengan materi yang berbeda untuk mendapatkan sertifikat keahlian level kualifikasi keahlian Teknik Instalasi Tenaga Listrik berdasarkan SKKNI.

\section{UCAPAN TERIMA KASIH}

Kegiatan PkM Program Kemitraan masyarakat ini terlaksana berkat kerjasama beberapa pihak, diantaranya; pengurus dan anggota Karang Taruna RW 14, Kepala Desa Ciwaruga, Ketua RW 14 dan Unit Penelitian dan Pengabdian Masyarakat (UPPM) Politeknik Negeri Bandung. Adapun dana Program Kemitraan Kepada Masyarakat ini berasal dari DIPA Politeknik Negeri Bandung sesuai dengan Surat Perjanjian Pelaksanaan Pengabdian Kepada Masyarakat 
skema Program Kemitraan Masyarakat No. 352.16/PL1.R7/PM/2019, tanggal 29 Mei 2019. Oleh karena itu, kami ucapkan atas partisipasi semua pihak atas terlaksananya kegiatan ini.

\section{REFERENSI}

[1] KEPMENAKERTRANS, "Penetapan Standar Kompetensi Kerja Nasional Indonesia Sektor Listrik Sub Sektor Ketenagalistrikan Bidang Instalasi Pemanfaatan Tenaga Listrik," dalam Keputusan Menteri Tenaga Kerja dan Transmigrasi Republik Indonesia Nomor: KEP.170/ MEN/IV/2007, Jakarta, 2007, pp. 119.

[2] D. Mulyadi, "Gambar Lisrtik," Jurusan Teknik Konversi Energi Politeknik Negeri Bandung, Bandung, 2011.

[3] P. T. I. d. K. K. BSN, Persyaran Umum Instalasi Listrik 2011 (PUIL 2011), penyunt., Jakarta: $\mathrm{Ba}$ dan Standarisasi Nasional, 2011.

[4] Sufiyanto, B. Sayogo dan A. Rusdiadi, "Keselamatan dan Pemasangan Instalasi Listrik Voltase Rendah untuk Rumah Tangga PUIL $2011+$ Amandemen 1 (2011)," Jakarta: Kementrian Energi dan Sumber Daya Mineral, 2016.

[5] Sayogo, F. Widjaja, S. T. Sinaga, Soemarjato, D. S. Soetarman dan S. Simangunsong, "Penjelasan PUIL 2011 (Persyaratan Umum Instalasi Listrik 2011)," penyunt., Jakarta: Kementrian Energi dan Sumber Daya Mineral, 2014.

[6] R. Setiabudy, Isdawimah, S. Wardono dan Ismujianto, "Pelatihan Instalasi Listrik Tegangan Rendah untuk Meningkatkan Keterampilan Anak Putus Sekolah (Studi Kasus di Paminjahan-Bogor)," Dhamakarya: Jurnal Aplikasi Ipteks untuk Masyarakat, vol. 1 No. 2, pp. 8086, 2012. 